\title{
ALBRECHT VON HALLER
}

1708-1777 


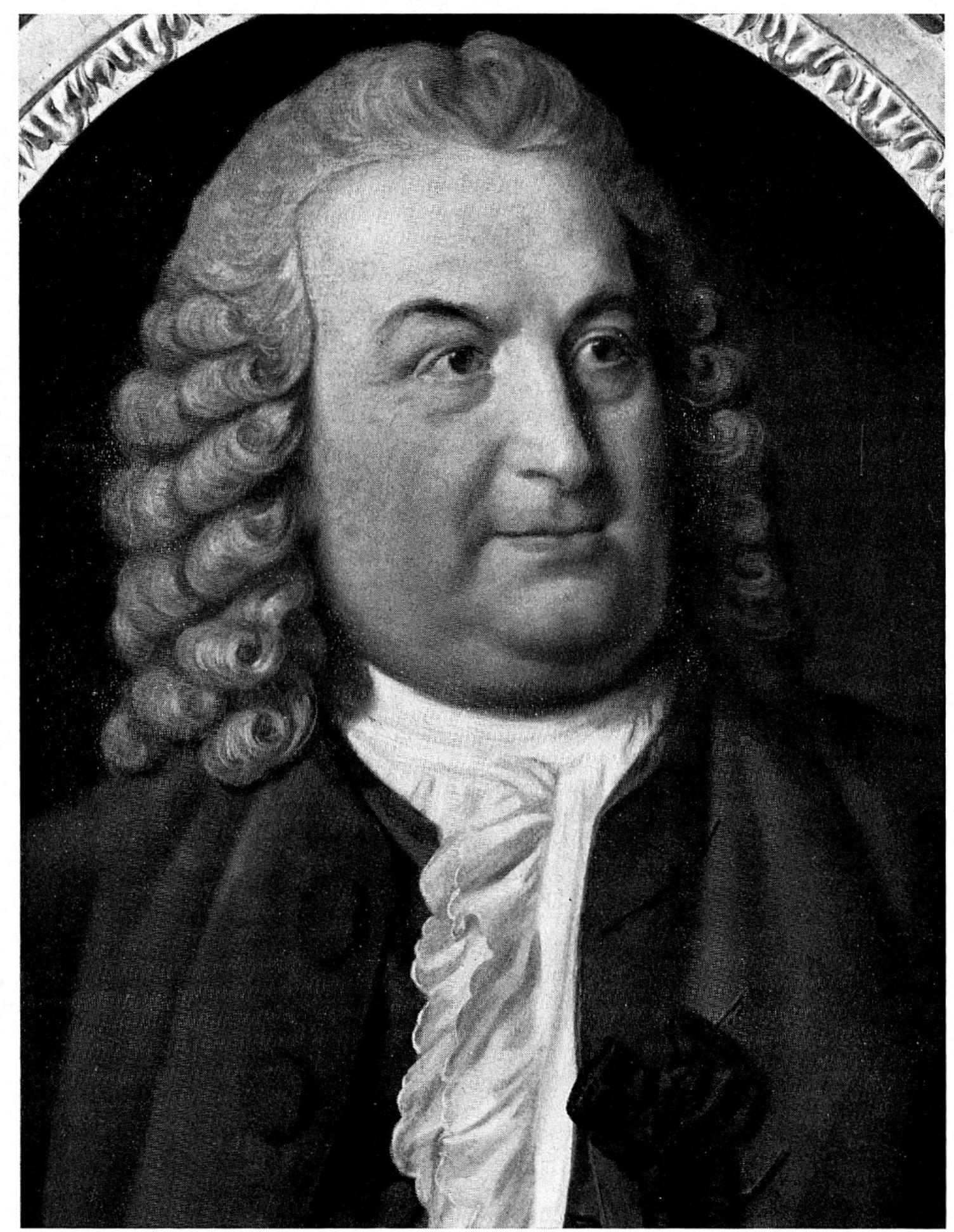

Albrecht von Haller, 1773 gemalt von Sigmund Freudenberger (Original bei Renaud de Haller, Carouge, aufgenommen von Gerhard Howald) 